\title{
IAMJ
}

INTERNATIONAL

AYURVEDIC

MEDICAL JOURNAL

\section{EXPOSITION OF PRINCIPLES OF SUPRAJA (EUGENICS) IN CHARAKA SAMHITA}

\author{
Snehal Bhaurao Akhare', Dipali Jayesh Agrawal ${ }^{2}$ \\ ${ }^{1}$ Lect in Streerog Avum Prasutitantra. S.S.V.P Ayurved College, Hatta. Hingoli, Maharashtra, India \\ ${ }^{2}$ Lect in Rognidan S.S.V.P Ayurved College, Hatta. Hingoli, Maharashtra, India
}

Corresponding Author: snehalakhare25@gmail.com

https://doi.org/10.46607/iamj2908122020

(Published online: December 2020)

Open Access

(C) International Ayurvedic Medical Journal, India 2020

Article Received: 30/11/2020 - Peer Reviewed: 01/12/2020 - Accepted for Publication: 03/12/2020

(D) Check for updates

\begin{abstract}
As per theory of eugenics, human race will be benefitted by producing fit and well born children. There are many ways to attain this but can prove dreadful too. Ayurveda, especially Charaka Samhita, provides a crisp and clear ideology about how each and every human can beget a superior progeny i.e. Supraja. The wisdom is found strewn across Charak Samhita. The present review is an attempt to piece together relevant references and provide a roadmap towards principles of Supraja or eugenics from Charaka Samhita. As healthy mind resides in a healthy body, such mentally and physically fit children will be a boon to the future generations to come, as our survival depends on them.
\end{abstract}

Keywords: Conception, Vajikarana, Beeja, Garbha, Charaka

\section{INTRODUCTION}

As multiple global health concerns go on rise so does the quest to solve them. One of the important solutions sought after is producing competent humans. This notion is often termed as Eugenics. A British anthropologist, Sir Francis Galton, in his work from 1869, coined the term "eugenics," meaning "well born," and theorized that humanity could be improved by encouraging the fittest members of society to have more children. ${ }^{1}$ But, this theory and its practice ultimately went horribly wrong despite its noble aims as evident from various documented unethical events ${ }^{2}$. While the world is precautious of this idea, a ray of 
hope can be found in the much sophisticated and scientific philosophy of Ayurveda. Since centuries, Ayurveda has sought after promotion of wellness with a harmonious relation of healthy body-mind and soul. Ayurveda has been regarded as good for both the worlds - the present and the after-life ${ }^{3}$.According to Ayurveda, the four basic goals of human life are Dharma (religion), Artha (economy), Kama (pleasure) and Moksha (salvation). Also, there exist three basic desires in human beings- longevity, wealth, and a heavenly afterlife ${ }^{4}$. Good health is the means to achieve all these goals.

Need of the Study: Charaka Samhita is considered as the premiere treatise of Ayurveda especially in area of therapeutics. It has been revered through ages for its all-encompassing and crisp ideologies regarding Ayurveda as a way of life. Thus, it was decided to limit the scope of this article to Charak Samhita.

Materials and Methods: The Charaka Samhita along with its Ayurveda - Deepika commentary by Chakrapani Datta was reviewed as primary source of information. Various references scattered through it were enlisted and careful deliberation was done over it. Scholarly articles, books etc. were also referred wherever needed.

\section{RESULTS AND DISCUSSION}

While ascertaining the need of Vajikarana (aphrodisiac treatments), it has been specified by Charaka Samhita that, Vajikarana is essentially for begetting a healthy progeny. A healthy progeny is in turn the means to attain Dharma, Artha, Preeti and Yasha $a^{5}$. Thus, importance of having Supraja or healthy children has been underlined at the very start of narration of aphrodisiacs. The conception happens when the Yoni (female genital tract) is devoid of any abnormalities and the Beeja (sperm and ovum) are normal in their proper form \& undamaged, and the Jivatama wants to enter into the Garbha (fetus) ${ }^{6}$. This seemingly uncomplicated phenomenon is evidently not so simple. Charaka Samhita has deliberated on each and every aspect of the prerequisites of conception. All men with physical strength don't seem to possess progeny soon ${ }^{7}$. It is a point to ponder that
Charaka has clearly mentioned about not correlating physical appearance of a man with his virility and ability to produce a superior progeny. This correlation or lack of correlation is basis of thought about Beeja or the smallest factor in human body responsible for reproduction.

While explaining embryogenesis; accustomed, wholesome regimen or Satmya has been attributed as a factor in formation and development of embryo. Charaka says that, the sterility of man and woman or defects in the embryo never happen without resorting to unwholesome practices. They are capable of reproduction as long as the Shukra (semen), Shonita (ovum), and Garbhashaya (uterus) are not afflicted by the vitiated doshas in the body, due to indulgence in unwholesome practices $^{8}$. Though not solely responsible for embryogenesis, Satmya attributes to important factors such as vigor, vitality, libido and excellence of fertility. In the same chapter, a very important statement has been made by Acharya Charaka, which reminds us about gene theory. It states that, if the part of the Beeja responsible for the development of a specific organ is afflicted, the respective organ will get afflicted too ${ }^{9}$. However, if the Beeja is not afflicted, there would be no affliction of the respective organ. So, both the possibilities are there. Also, due to involvement of Karma, certain qualities of parents do not get inflicted in their progeny. Here, Beeja represents both sperm and ovum. It is curious to know that wisdom of Charaka is not limited to these minute scale factors but extends further to their fractions too. A number of examples can be seen in Charaka Samhita to strengthen this Beeja Siddhanta. For instance, while elaborating treatment of Prameha and Madhumeha, both congenital and hereditary factors have been described. Congenital or hereditary Prameha and Madhumeha are incurable due to morbidity in parental Beeja ${ }^{10}$. Similarly, other Kulaja i.e. hereditary /familial ailments are considered as incurable. Similarly, congenital hemorrhoids are caused by the vitiation of the deformity in Beeja Dosha, specially the part that is responsible for formation of the anal canal or anal sphincters. The impropriety of Beeja can affect 
reproductive system of the progeny to produce Klaibya in males ${ }^{11}$ and Yonivyapad in females ${ }^{12}$. The scope of eugenics is not just limited to reproductive system and its macro and microscopic elements. For birth of a human with wholesome health, many other extrinsic factors play a vital role. Tridosha Siddhanta is the pillar of Ayurveda. No bodily event may happen without involvement of either or every Dosha. Vata Dosha in its normalcy maintains the body and controls all the activities. Shaping of embryo and molding it into normal shape and size has been attributed to Vata Dosha. When aggravated, the almighty Vata has power to destroy, deform and retain the embryo in uterus for longer period that normal ${ }^{13}$. Also, Vata Dosha is controller and prompter of Manas ${ }^{14}$. Sound and happy state of mind is crucial for conception and its sustenance ${ }^{15}$. Hence, altogether it is a key factor in Supraja i.e. production of healthy progeny. The role of Pitta and Kapha Dosha has not been left out. During describing Doshaja Prakriti, persons with Pittala Prakriti are defined to have less sexual drive and fewer progeny as opposed to Shleshmala Prakriti, which is bestowed with profusion of sexual drive and progeny ${ }^{16}$. As far as Dhatusarata is considered, Majjasara and Shukrasara persons are described to be endowed with more progeny by nature ${ }^{17}$.As such, all the factors ranging from conception to delivery have been thoroughly explained by Charaka Samhita.

\section{CONCLUSION}

The fundamentals of Ayurveda are universal and inclusive. Many of the pressing concerns in modern obstetrics can be solved through Ayurveda. The product of conception i.e. Garbha is not just a union of gametes. Its very existence and materialization depend on many factors as described here. The insights from Ayurvedic classics are to shape and sharpen our skills. Thus, consideration of all such complex factors can contribute effectively to generation of Supraja. As healthy mind resides in a healthy body, such mentally and physically fit children will be a boon to the future generations to come, as our survival depends on them.

\section{REFERENCES}

1. Norrgard, K. (2008) Human testing, the eugenics movement, and IRBs. Nature Education 1(1):170, Available from: https://www.nature.com/ scitable/topicpage/ human-testing-the-eugenicsmovement-and-irbs-724/

2. Garver, K. L., \& Garver, B. (1991). Eugenics: past, present, and the future. American journal of human genetics, 49(5), 1109-1118. PMID: 1928094; PMCID: PMC1683254. Available from: https://www.ncbi.nlm.nih.gov/ pmc/ articles/ PMC1683254/

3. Agnivesha, Charaka Samhita with Ayurveda Deepika commentary of Chakrapanidatta, edited by Vaidya Yadavji Trikamji Acharya, Published byChaukhambha Surbharati Prakashan, Varanasi, Reprint Edition 2011; Sutra Sthana Ch:1/43, p. 8

4. Agnivesha, Charaka Samhita with Ayurveda Deepika commentary of Chakrapanidatta, edited by Vaidya Yadavji Trikamji Acharya, Published byChaukhambha Surbharati Prakashan, Varanasi, Reprint Edition 2011; Sutra Sthana Ch:11/3, p. 67

5. Agnivesha, Charaka Samhita with Ayurveda Deepika commentary of Chakrapanidatta, edited by Vaidya Yadavji Trikamji Acharya, Published byChaukhambha Surbharati Prakashan, Varanasi, Reprint Edition 2011; Chikitsa Sthana Ch:2-1/4, p. 390

6. Agnivesha, Charaka Samhita with Ayurveda Deepika commentary of Chakrapanidatta, edited by Vaidya Yadavji Trikamji Acharya, Published byChaukhambha Surbharati Prakashan, Varanasi, Reprint Edition 2011; Chikitsa Sthana Ch:30/125, p. 639

7. Agnivesha, Charaka Samhita with Ayurveda Deepika commentary of Chakrapanidatta, edited by Vaidya Yadavji Trikamji Acharya, Published byChaukhambha Surbharati Prakashan, Varanasi, Reprint Edition 2011; Chikitsa Sthana Ch:2-4/5, p. 395

8. Agnivesha, Charaka Samhita with Ayurveda Deepika commentary of Chakrapanidatta, edited by Vaidya Yadavji Trikamji Acharya, Published byChaukhambha Surbharati Prakashan, Varanasi, Reprint Edition 2011; Sharira Sthana Ch:3/11, p. 312

9. Agnivesha, Charaka Samhita with Ayurveda Deepika commentary of Chakrapanidatta, edited by Vaidya Yadavji Trikamji Acharya, Published byChaukhambha Surbharati Prakashan, Varanasi, Reprint Edition 2011; Sharira Sthana Ch:3/17, p. 314 
10. Agnivesha, Charaka Samhita with Ayurveda Deepika commentary of Chakrapanidatta, edited by Vaidya Yadavji Trikamji Acharya, Published byChaukhambha Surbharati Prakashan, Varanasi, Reprint Edition 2011; Chikitsa Sthana Ch:6/57, p. 449

11. Agnivesha, Charaka Samhita with Ayurveda Deepika commentary of Chakrapanidatta, edited by Vaidya Yadavji Trikamji Acharya, Published byChaukhambha Surbharati Prakashan, Varanasi, Reprint Edition 2011; Chikitsa Sthana Ch:30/190, p. 642

12. Agnivesha, Charaka Samhita with Ayurveda Deepika commentary of Chakrapanidatta, edited by Vaidya Yadavji Trikamji Acharya, Published byChaukhambha Surbharati Prakashan, Varanasi, Reprint Edition 2011; Chikitsa Sthana Ch:30/8, p. 634

13. Agnivesha, Charaka Samhita with Ayurveda Deepika commentary of Chakrapanidatta, edited by Vaidya Yadavji Trikamji Acharya, Published byChaukhambha Surbharati Prakashan, Varanasi, Reprint Edition 2011; Sutra Sthana Ch:12/8, p. 79

14. Agnivesha, Charaka Samhita with Ayurveda Deepika commentary of Chakrapanidatta, edited by Vaidya Yadavji Trikamji Acharya, Published byChaukhambha Surbharati Prakashan, Varanasi, Reprint Edition 2011; Sutra Sthana Ch:12/8, p. 79

15. Agnivesha, Charaka Samhita with Ayurveda Deepika commentary of Chakrapanidatta, edited by Vaidya Yadavji Trikamji Acharya, Published byChaukhambha Surbharati Prakashan, Varanasi, Reprint Edition 2011; Sutra Sthana Ch:25/40, p. 131-132

16. Agnivesha, Charaka Samhita with Ayurveda Deepika commentary of Chakrapanidatta, edited by Vaidya Yadavji Trikamji Acharya, Published byChaukhambha Surbharati Prakashan, Varanasi, Reprint Edition 2011; Vimana Sthana Ch:8/96-97, p. 277

17. Agnivesha, Charaka Samhita with Ayurveda Deepika commentary of Chakrapanidatta, edited by Vaidya Yadavji Trikamji Acharya, Published byChaukhambha Surbharati Prakashan, Varanasi, Reprint Edition 2011; Vimana Sthana Ch:8/108-109, p. 278

\section{Source of Support: Nil \\ Conflict of Interest: None Declared}

How to cite this URL: Snehal Bhaurao Akhare \& Dipali Jayesh Agrawa: Exposition Of Principles Of Supraja (Eugenics) In Charaka Samhita. International Ayurvedic Medical Journal \{online\} 2020 \{cited December, 2020\} Available from: http://www.iamj.in/posts/images/upload/5372 5375.pdf 